\title{
Which Intelligence is Most Important in Forming the Entrepreneurial Spirit?
}

\author{
IMAS SOEMARYANI \\ Department of Management and Business, Universitas Padjadjaran, Bandung 40132, Indonesia \\ Email correspondence: imas.soemaryani@unpad.ac.id
}

\begin{abstract}
The role of entrepreneurs becomes more influential in the current business world. Due to lack of entrepreneurial spirit, many entrepreneurs experience unsuccessful result in their entrepreneurship journey. Entrepreneurial spirit results from a combination of someone's hereditary factors, experience, and environment. This gives HRM wide room of discussion to find suitable stimulating factors to improve entrepreneurial spirit. Growing evidence shows various intelligence can contribute to someone's entrepreneurial spirit including intellectual quotient, emotional quotient, spiritual quotient, social quotient, and adversity quotient. This research aims to examine which of each quotient has the most influential factor to the entrepreneurial spirit. This study was conducted using 30 small-and-medium-scale fashion entrepreneurs in Bandung and analyzed using weighting approach and ranking method. Based on the findings, this research suggests that SQ (Spiritual Quotient), followed by adversary quotient, has the strongest influence in shaping the entrepreneurial spirit.
\end{abstract}

Key words: Entrepreneurial Spirit, Intellectual Intelligence, Emotional Intelligence, Spiritual Intelligence, Social Intelligence, Adversary Intelligence.

\section{Kecerdasan Mana yang Paling Penting dalam Pembentukan Semangat Berwiraswasta?}

\begin{abstract}
Abstrak
Pengaruh peran wirausahawan menjadi sangat tinggi di dunia bisnis saat ini. Karena kurangnya semangat berwiraswasta (entrepreneurial spirit), banyak wirausahawan mengalami kegagalan dalam pengalaman berwirausaha mereka. Semangat berwiraswasta adalah hasil dari kombinasi faktor keturunan, pengalaman, dan lingkungan. Hal ini membuka ruang yang luas bagi manajemen SDM untuk menemukan formulasi yang tepat dalam menemukan stimulan yang mampu meningkatkan semangat berwirausaha. Semakin banyak penelitian menunjukkan bahwa berbagai kecerdasan dapat berkontribusi kepada semangat berusaha seseorang. Kecerdasan tersebut mencakup intellectual quotient (IQ), emotional quotient (EQ), spiritual quotient (SQ), social quotient, dan adversity quotient (AQ). Penelitian ini bertujuan untuk mencari tahu kecerdasan manakah yang paling berpengaruh pada semangat berwirausaha seseorang. Penelitian ini dilakukan pada 30 UMKM di bidang fesyen di Bandung. Data diolah menggunakan weighting approach dan metode peringkat. Berdasarkan hasil penelitian, artikel ini berpendapat bahwa SQ, diikuti oleh $A Q$, memiliki pengaruh terbesar dalam membentuk semangat berwirausaha.
\end{abstract}

Kata kunci: semangat berwirausaha, intellectual intelligence, emotional intelligence, spiritual intelligence, social intelligence, adversary intelligence. 


\section{INTRODUCTION}

Bandung is a city having won numerous predicates, namely as a city of education, culinary and creative city. UNESCO, on 25 September 2013, declared the city of Bandung as the World Tourism City. Those predicates indicate that Bandung has a variety of activities directly contributing to the local revenues significantly. In 2014, the trade, hotel and restaurant sectors contributed 40 percent to the GDP of Bandung, as shown in Table 1.

Table 1. GDP of Bandung on Constant Prices Year 2013-2014

\begin{tabular}{clcc}
\hline No. & \multicolumn{1}{c}{ Sector } & $\mathbf{2 0 1 3}$ & $\mathbf{2 0 1 4}$ \\
\hline 1. & Agriculture & $0.20 \%$ & $0.18 \%$ \\
2. & Manufacturing & $25.45 \%$ & $24.29 \%$ \\
3. & Electricity, Gas, and Water & $2.40 \%$ & $2.45 \%$ \\
4. & Building / Construction & $5.02 \%$ & $5.19 \%$ \\
5. & Trade, Hotel, and Restaurant & $39.82 \%$ & $40.81 \%$ \\
6. & Transport and Communication & $11.05 \%$ & $11.30 \%$ \\
7. & Finance, Real Estate, and Business Services & $5.27 \%$ & $5.15 \%$ \\
8. & Services & $10.78 \%$ & $10.63 \%$ \\
TOTAL & & $100 \%$ & $100 \%$ \\
\hline
\end{tabular}

Source: Data from the Central Statistics Agency of Bandung in 2015

The significant contribution from the sector of trade, hotels, and restaurants cannot be separated from the role of entrepreneurs engaged in these fields. One industry that stands in Bandung is the fashion industry. Based on data from BPPKU chamber of commerce of Bandung (KADIN) until 2014, there were 894 businesses classified as micro, small and medium enterprises in the fashion industry. Other industries and their order can be seen in Table 2 as follows.

Table 2. Number of SMEs supporting tourism industry registered in BPPKU KADIN Bandung 2014

\begin{tabular}{cc}
\hline Industry & Total \\
\hline Fashion & 894 \\
Handicraft & 385 \\
Food \& Beverage & 581 \\
Miscellaneous & 148 \\
\hline
\end{tabular}

Source: BPPKU KADIN Bandung (processed), 2015

In its existence, the fashion industry is expected to contribute even more along with the city of Bandung designated as a city of the world tourism. This industry is demanded to make Bandung became the center of fashion internationally. To realize this dream, the high competence of entrepreneurs engaged in this area is a must. Besides, to support the improvement of this high competence, the various intelligence possessed as a foundation for achieving the goal must be owned by the entrepreneurs. By having the various intelligence (ranging from intellectual, social, emotional, spiritual, adversity intelligence) in accordance with the demands, the entrepreneurs are expected to enhance their entrepreneurial spirit. Finally, with the high entrepreneurial spirit, there will be an improvement in performance both individual and the organization or the company.

This research develops the ranking of types of intelligence that should be possessed by small and medium entrepreneurs in the fashion industry in Bandung, so it can be used as a reference in determining the model of intelligence needed. It also designs the intelligence model of small and medium entrepreneurs in the fashion industry in Bandung, so it can be used as an input in arranging the selection and development program of human resources, especially the entrepreneurs of the fashion industry in Bandung.

\section{LITERATURE REVIEW}

\section{Entrepreneurship and Entrepreneurial Spirit}

Firms and businesses are the results of entrepreneurs' contribution in taking the risk of trial-and-error, deciding whether or not to found a firm, and responding to certain and uncertainty around the business by making a decision. They are procedurally rational, subjective due to intuition, and experience based learners. In the early stage, entrepreneurs are challenged with uncertainties from economic development and the dynamics from business sectors. At this stage, knowledge, and experience result in natural selection, leaving actors with qualified entrepreneurial behavior to develop and grow (Grebel, Pyka, \& Hanusch, 2003).

Throughout the cycle, the uncertainty from external environment factors (economy, competitor, society, government policy) requires entrepreneurs to have an entrepreneurial spirit. In many situations, along historical events of entrepreneurship 
cases, entrepreneurial spirit is reflected in some characteristics: (i) risk-taking associated with the various decisions taken; (ii) he has the initiative in making effort to open opportunities or build activities that benefit himself and others; (iii) he is disciplined in his life in his business activities; (iv) he has a high commitment to support the achievement of the business success; ( $v$ ) he is honest to build confidence and credibility from all parties such as business partners, creditors, customers and other interested parties; (vi) he is creative and innovative reflected from the high creativity, strong intuition, broad insights; (vii) he is independent and reasonable reflected from the way of building himself without depending on anyone else, dynamic, and always looks at life and the development of the business realistically (Beltran \& Miguel, 2014).

With these characteristics, an entrepreneur usually has certain capabilities, among others are: (a) the ability to open, search, create, and utilize the opportunity; (b) the ability to discover something new; (c) the ability to bring together the factors of production or organize companies effectively and efficiently; (d) the ability to adapt to the business environment, society, and government; (e) the ability to make decisions and minimize risks; (f) the ability to utilize existing facilities and technologies; (g) the ability to compete with others.

It has been a long debate to what extent inherited trait contribute to the end output of characteristics and behavior. Many findings supporting the theory of evolution believes that traits and characteristics, including entrepreneurial spirit, are heritable (Galor \& Michalopoulos, 2009). Five-factor personality theory argues that heritable characteristics develop following the physical age and reach maturity and stability in adulthood (McCrae \& Costa, 1999). Another approach argued that characteristics are the result of heritable traits and environment force across the life course (Levinson, 1978). Entrepreneurial spirit can also improve the time and adaptation factors have the more dominant influence to shape a person (Baltes, 1997). There is growing evidence that not all entrepreneurs inherited their entrepreneurs' behavior to their children although it was what they expected (Chakraborty, Thompson, \& Yehoue, 2016). It was supported by a study examining students in
41 European universities who own start-up business. The study found that while personal characteristics are fundamental, the student's environment also dominantly contribute to their entrepreneurship progress (Bergmann, Hundt, \& Sternberg, 2016). This belief provides wide room discussion in HRM studies on how to stimulate people to increase their entrepreneurial spirit.

\section{Intelligence}

Growing evidence shows a strong impact of multiple intelligence on entrepreneurial behavior (Demirel, Dusukcan, \& Olmez, 2012). Intelligence is a capacity of the individual required to support the completion of various jobs well and it will finally able to contribute to the achievement of a high performance (Aristarini, et al, 2014; Robbins \& Judge, 2013). The common individual has a unique set combination of multiple intelligence. Multiple Intelligence has been classified into specific categories;

First intelligent Quotient (IQ) is the individual's ability to think, process, and control the environment maximally as well as to act as directed (Aristarini et al, 2014). It is used to solve logic or strategic problems. It involves the process of thinking rationally, analyzing, and understanding It is hard to observe directly and must be inferred from all the real actions which are the manifestation of the process of rational thinking.

Second emotional intelligence or Emotional Quotient (EQ) is the ability to identify, control and organize own feelings and the feelings of others in depth so that his presence is pleasant and desirable to others (Aristarini et al, 2014). Goleman's classic model of emotional intelligence formulates El into five components self-awareness self-regulation, motivating oneself, empathy, and handling relationship (Goleman, 1995). Research also found that emotional intelligence moderate the effects of emotional expression and the growth of perseverance in difficulties (Linley et al, 2011).

Third spiritual intelligence or Spiritual Quotient (SQ) is difficult to define as the construct involved in spirituality has multi perceptions influenced by different personal experience, understanding, and activities (Singiliene \& Skeriene, 2015). This research use $S Q$ framework that is associated with the source 
inspiring and catapulting someone's spirit by attaching himself or herself to the values of the truth indefinitely (Aristarini et al, 2014). This intelligence is used to distinguish between good and bad, right and wrong, and understand the moral standard. This intelligence acts as a necessary basis for the proper and effective functioning of $I Q$ and $E Q$. In fact, $S Q$ is the highest intelligence in ourselves. From this statement, it is clear that SQ alone cannot solve the problem because it needs to be balanced by emotional and intellectual intelligence

Fourth social Intelligence (SI) which is the ability reaching the maturity of the thought and action in carrying out the role of human as a social being in a relationship with the environment or community. This intelligence is the achievement of the human qualities regarding the self-awareness and mastery of knowledge used not only for the success in interpersonal relations but also for providing benefits to the surrounding community. Social intelligence will give us sharpness and clarity in seeing the problem (Suyono, 2007). The problem will be solved properly because the individuals or groups who have social intelligence will look at things objectively. They will assess an event fairly and skillfully so it prevents them from the aggressive behavior.

Fifth physical intelligence is the intelligence necessary to perform tasks requiring stamina, dexterity, strength and other physical skills.

Sixth AQ (Adversity Quotient) as highlighted by Paul $G$ Stoltz highlighted is essentially the intelligence associated with the capacity of dealing with stress, solving problems and finding solutions. This skill does not appear just it is. The ability to resolve the problems and survive in trouble without giving up could have an impact for decades in the future. This will not only make a person graduate from a higher education but also pass the storm in his life. The point is, $A Q$ is the intelligence in facing difficulties or obstacles and the ability to survive and in various hardships and challenges (Aristarini et al, 2014).

In summary, those intelligences are needed to support the achievement of performance and foster the entrepreneurial spirit. This research aims to answer 'which human intelligence has the most influential factor in improving entrepreneurial spirit'.

\section{RESEARCH MRTHODS}

This study was conducted by using explanatory survey. The data processing method approach is the Analytical Hierarchy Process (AHP), whereas the method of analysis used is descriptive analysis. This research utilizes 30 fashion entrepreneurs located in Bandung, West Java, Indonesia.

\section{RESULTS AND DISCUSSION}

\section{Profile of SMEs Fashion}

The 30 entrepreneurs studied in this research are in the fashion industry. They are shown as follows:

Table 3. Profile of SMEs Fashion in Bandung

\begin{tabular}{|c|c|c|c|}
\hline No & Description & Classification & Percentage \\
\hline \multirow[t]{2}{*}{1.} & Business Scale & Small & 43.33 \\
\hline & & Medium & 56.66 \\
\hline \multirow[t]{4}{*}{2.} & Product Produced & Muslim Clothing & 26.66 \\
\hline & & $\begin{array}{l}\text { Specialized in Men's } \\
\text { clothing }\end{array}$ & 46.67 \\
\hline & & $\begin{array}{l}\text { Specialized in Women's } \\
\text { clothing }\end{array}$ & 20.00 \\
\hline & & General Clothing & 6.67 \\
\hline \multirow[t]{4}{*}{3.} & Business Length & 1-3 Years & 10.00 \\
\hline & & 4-6 Years & 26.67 \\
\hline & & 7-9 Years & 46.67 \\
\hline & & $>10$ Years & 16.66 \\
\hline \multirow[t]{3}{*}{4.} & Education Level & Junior High School & 13.33 \\
\hline & & Senior High School & 56.67 \\
\hline & & $\begin{array}{l}\text { Bachelor Degree \& } \\
\text { Diploma }\end{array}$ & 30.00 \\
\hline
\end{tabular}

Source: Primary Data processed, 2015

\section{Rank of intelligence}

The six types of intelligences identified to be able to influence and contribute to shaping the entrepreneurial spirit can be seen in table 5 .

This rank is obtained from the calculation of the following stages: (i) giving equal weight to the six intelligences with the assumption that all intelligences have the same importance. Thus, the total weight (or 1 ) divided by the six types of intelligences is 0.17 ; (ii) asking the respondents to rank the level of intelligence which from the most to the least important, meaning that the respondents were asked to rank the type of intelligence which is really needed and contributes 
the most to the fostering of the entrepreneurial spirit; (iii) multiplying the weight with the value of the ranking given by the respondents, and the results can be seen in Table 4.

Table 4. Rankings of Intelligences

\begin{tabular}{clccc}
\hline No. Intelligence Type & Weight & $\begin{array}{c}\text { Rank of } \\
\text { Importance }\end{array}$ & $\begin{array}{c}\text { Value of } \\
\text { Importance } \\
\text { Level }\end{array}$ \\
\hline 1 & Intelligent Quotient & 0.14 & 3 & 0.42 \\
2 & Spiritual Quotient & 0.14 & 7 & 0.98 \\
3 & Emotional Quotient & 0.14 & 2 & 0.28 \\
4 & Social Quotient & 0.14 & 4 & 0.56 \\
5 & Physical Quotient & 0.14 & 1 & 0.14 \\
6 & Adversity Quotient & 0.14 & 6 & 0.84 \\
7 & Culture-Art Quotient & 0.14 & 5 & 0.7 \\
\hline
\end{tabular}

Source: Primary data processed, 2015

Note: the greater numeric value indicates the higher level of importance.

Table 4 gives the sense that in the environment of the fashion industry, the intelligence which is most important and contributes the most to foster the entrepreneurial spirit is the spiritual intelligence, followed by intelligence in facing and solving the problems, social intelligence, intellectual intelligence, emotional intelligence and the last is physical intelligence.

The results also meant that in nurturing and enhancing the entrepreneurial spirit, (especially in the fashion industry in Bandung), a high morale is the most important, followed by high confidence, positive thinking, keeping the promises to anyone, being reliable, doing good deeds to others and having a principle of not harming others.

Seeing the indicators of spiritual intelligence above, it makes sense that the spiritual intelligence is considered the most capable of forming the entrepreneurial spirit because a good entrepreneur must be a: (i) risk taker or the one who has the ability to take risks from all decisions he has taken, (ii) person with a clear vision, mission, and goal, and to achieve this it takes a strong sense of success; (iii) a person who keeps his promises and is honest and has a high commitment. The interesting things found in this study are the two types of intelligence that have been rarely mentioned namely adversary intelligence and art and cultural intelligence. It is understandable that art and cultural intelligence are the concern in the fashion industry because fashion is strongly associated with art and culture.

\section{Indicator Level of Intelligence Level Spiritual Intelligence (Spiritual Quotient)}

Some of the indicators used as basis to measure the spiritual intelligence in this study are: (i) ability to take risk; (ii) ability to clearly define the vision, mission and goals to be achieved; (iii) confidence in the success of what is being done; (iv) the spirit or motivation to strive; (v) ability of positive thinking; (vi) keeping the promises; (vii) doing good and; (viii) always taking lessons from any event.

Of the eight indicators used as benchmarks of the spiritual intelligence, the factor which influences entrepreneurial spirit the most is motivation or high morale, followed by the belief or confidence in the success of what is being done. For the entrepreneurs, motivation and strong will are the keys to success. The logic behind it is if someone does not have a strong will, he will be so weak when facing obstacles or difficulties. In general, motivation and a strong will are also driven by a strong belief that the success will be achieved when there is a strong effort to achieve it. The complete picture of the indicator level of the spiritual intelligence can be seen in Table 5 .

Table 5. Indicator of Spiritual Intelligence

\begin{tabular}{|c|c|c|c|c|}
\hline No & Intelligence Indicator & Weight & Rating & Score \\
\hline 1 & Ability in designing & 0.2 & 5 & 1.00 \\
\hline 2 & $\begin{array}{l}\text { Instinct Ability/a good business instinct in } \\
\text { fashion field }\end{array}$ & 0.2 & 2 & 0.4 \\
\hline 3 & Ability to read the market situation & 0.2 & 3 & 0.6 \\
\hline 4 & $\begin{array}{l}\text { Ability to communicate in a good } \\
\text { language }\end{array}$ & 0.2 & 4 & 0.8 \\
\hline 5 & Ability in counting or calculating / numeric & 0.2 & 1 & 0.2 \\
\hline 6 & Keeping the promises & 0.125 & 2 & 0.25 \\
\hline 7 & Doing good & 0.125 & 3 & $12: 38$ \\
\hline 8 & Always taking lessons from any event & 0.125 & 1 & 0.125 \\
\hline
\end{tabular}

Sources: Primary data processed, 2015

\section{Intellectual Intelligence}

In the context of this study, Intellectual intelligence relates to the ability to understand everything related to the fashion business to understand both knowledge concept and skill. There are five indicators used to measure the intelligence quotient. Of the 
five of these indicators, the factor which forms the entrepreneurial spirit the most is a willingness to design, followed by the ability to communicate in a proper language.

It is fair that both of these indicators provide the largest contribution to shaping the entrepreneurial because: (a) the entrepreneurs are engaged in fashion industry, so the knowledge and understanding of both the concepts and skills related to the design are absolutely needed; (b) the ability of designing becomes meaningless when the entrepreneurs are unable to communicate well by giving a good explanation on the design results. Therefore, the communication capability using a good language is highly demanded in this industry. The complete picture of the rank of the spiritual intelligence indicators can be seen in Table 6.

Table 6. The Score of Intellectual Intelligence

\begin{tabular}{clccc}
\hline No & Indicator Intelligence & Weight & Rating & Score \\
\hline 1 & Ability in designing & 0.2 & 5 & $1: 00$ \\
2 & $\begin{array}{l}\text { Instinct Ability/a good business instinct in } \\
\text { fashion field }\end{array}$ & 0.2 & 2 & 0.4 \\
3 & Ability to read the market situation & 0.2 & 3 & 0.6 \\
4 & Ability to communicate in a good & 0.2 & 4 & 0.8 \\
& language & & & \\
5 & Ability in counting or calculating / numeric & 0.2 & 1 & 0.2 \\
\hline
\end{tabular}

Sources: Primary data processed, 2015

\section{Emotional Intelligence}

Of the seven indicators used to measure the emotional intelligence, the ability to have a high self-awareness is the most influential in forming the entrepreneurial spirit. The second indicator is the ability to accept criticism and suggestions. According to the entrepreneurs observed, the important factor shaping the entrepreneurial spirit is the selfawareness of who we are. This is because the one who understands and knows better about the strengths and weaknesses is him or herself. Therefore, he or she knows exactly how to behave, what to prepare etc. If someone is aware of himself, he should be able to receive advice, criticism, and opinions from others. The weakness of common people is, people are usually able to criticize others but difficult to accept suggestions and criticisms from others. An entrepreneur must not be like that, instead, he must be able to accept criticism and suggestion because by doing that, he will always be able to improve and develop himself. The complete picture of the rank of spiritual intelligence indicators can be seen in Table 7 .

Table 7. The Score of Emotional Intelligence

\begin{tabular}{clccc}
\hline No & Intelligence Indicator & Weight & Rating & Score \\
\hline 1 & Empathy & 0.14 & 6 & 0.84 \\
2 & Ability to control mood or self-control & 0.14 & 2 & 0.28 \\
3 & $\begin{array}{l}\text { Ability to accept criticism and suggestions } \\
\text { from others }\end{array}$ & 0.14 & 5 & 0.7 \\
4 & & & \\
5 & Huge curiosity & 0.14 & 4 & 0.56 \\
& Ability to take responsibility for what is & 0.14 & 3 & 0.42 \\
& done & & & \\
6 & High self-awareness & 0.14 & 7 & 0.98 \\
7 & Ability to control conflicts & 0.14 & 1 & 0.14 \\
\hline
\end{tabular}

Sources: Primary data processed, 2015

\section{Social Intelligence}

Within the fashion industry, the indicators of social intelligence which are the most influential in forming the entrepreneurial spirit are the ability to convey ideas persuasively and the ability to search network with various parties. The idea is to develop a business, there is a need to have people with the ability to create ideas persuasively. When the idea is already created, there is a need to know to whom the ideas will be presented. So, the ability to search business network from the various groups or target market is very influential in forming the entrepreneurial spirit. The complete picture of the rank of the social intelligence indicators can be seen in Table 8.

Table 8. The Indicators of Social Intelligence

\begin{tabular}{llccc}
\hline No & Intelligence Indicator & Weight & Rating & Score \\
\hline 1 & $\begin{array}{l}\text { Ability to establish a good working } \\
\text { relationship with various parties }\end{array}$ & 0.17 & 3 & 0.51 \\
2 & $\begin{array}{l}\text { Ability to search the network from various } \\
\text { parties }\end{array}$ & 0.17 & 5 & 0.85 \\
3 & $\begin{array}{l}\text { Ability to understand and be sensitive to } \\
\text { the needs and rights of other people }\end{array}$ & 0.17 & 1 & 0.17 \\
4 & $\begin{array}{l}\text { Ability to adjust (presence) in certain } \\
\text { situations }\end{array}$ & 0.17 & 2 & 0.34 \\
5 & $\begin{array}{l}\text { Ability to be trustworthy } \\
6\end{array} \quad$ Ability to convey ideas persuasively & 0.17 & 6 & 1.02 \\
\hline Source:Primary Pata processed 2015 & & 0.17 & 0.68
\end{tabular}

Source: Primary data processed, 2015

\section{Physical Intelligence}

The physical intelligence is often untouched in the discussion of human resources management. In the context of this study, the physical intelligence is also 
considered. The logic is a good businessman should be able to perform various activities that require a good physical condition. Having a good motor skill such as moving speed, accuracy, and flexibility is an influential indicator in shaping the entrepreneurial spirit. In addition to a good physical motoric, the mental health in reasoning is also needed in running a business activity. The complete picture of the rank of the physical intelligence indicators can be seen in Table 9.

Table 9. The Indicators of Physical Intelligence

\begin{tabular}{clccc}
\hline No & Indicator Intelligence & Weight & Rating & Score \\
\hline 1 & Has a physical endurance in work & 0.17 & 2 & 0.34 \\
2 & Has good motoric skill & 0.17 & 6 & 1.02 \\
3 & Has a good health & 0.17 & 3 & 0.51 \\
4 & $\begin{array}{l}\text { Has the ability to adjust to the working } \\
\text { place }\end{array}$ & 0.17 & 1 & 0.17 \\
5 & $\begin{array}{l}\text { Has the power of reasoning in accordance } \\
\text { with the age }\end{array}$ & 0.17 & 5 & 0.85 \\
6 & $\begin{array}{l}\text { Has a body structure in accordance with } \\
\text { the age }\end{array}$ & 0.17 & 4 & 0.68 \\
\hline Sources: Primary data processed 2015 & & & \\
\hline
\end{tabular}

\section{Adversary Quotient (AQ)}

Adversary Quotient is in the second rank of the most influential in forming the entrepreneurial spirit in the fashion industry in Bandung. The foundation is when an entrepreneur has a strong motivation and high confidence in what is being done, its implementation would not be as smooth as planned. There will be many obstacles, challenges, and problems that may arise in the journey. Therefore, this intelligence is instrumental in shaping the entrepreneurial spirit, especially the ability to survive and solve the problems. The complete picture of the rank of the adversary intelligence indicators can be seen in Table 10.

Table 10. The Indicators of Quotient Adversary (AQ)

\begin{tabular}{clccc}
\hline No & Intelligence Indicator & Weight & Rating & Score \\
\hline 1 & Ability to handle stress & 0.2 & 1 & 0.2 \\
2 & Ability to solve problems & 0.2 & 3 & 0.6 \\
3 & Ability to seek a solution in resolving issue & 0.2 & 4 & 0.8 \\
4 & Ability to survive in difficulties / barriers & 0.2 & 5 & 1.00 \\
5 & $\begin{array}{l}\text { Ability to understand the one's strengths } \\
\text { and weaknesses }\end{array}$ & 0.2 & 2 & 0.4 \\
\hline
\end{tabular}

Sources: Primary data processed, 2015

\section{Cultural and Arts Intelligence}

Because the unit of analysis in this study is the entrepreneurs in the field of the fashion industry which is inseparable from the elements of art and culture, growing and nurturing the entrepreneurial spirit needs to be supported by cultural and artistic intelligence. Among the six indicators used to measure the art and cultural intelligence, the ability to appreciate arts and culture is the main key, followed by the ability to observe the art and culture. The foundation is to express something related to the arts and culture must be begun with loving the art and culture beforehand. Afterwards, there usually appears the desire to observe, make and subsequently express. The complete picture of the rank of the cultural and art intelligence indicators can be seen in Table 11.

Table 11. The Score of Arts and Cultural Intelligence

\begin{tabular}{clccc}
\hline No & Intelligence Indicator & Weight & Rating & Score \\
\hline 1 & Ability to appreciate culture and arts & 0.17 & 6 & 1.02 \\
2 & Ability to observe culture and art & 0.17 & 5 & 0.85 \\
3 & Ability to distinguish art and culture & 0.17 & 1 & 0.17 \\
4 & Ability to fabricate art and culture & 0.17 & 2 & 0.34 \\
5 & $\begin{array}{l}\text { Ability to establish/create arts and culture } \\
\text { related to fashion }\end{array}$ & 0.17 & 3 & 0.51 \\
6 & $\begin{array}{l}\text { Ability to express art and culture into the } \\
\text { design of fashion }\end{array}$ & 0.17 & 4 & 0.68 \\
\hline
\end{tabular}

Sources: Primary data processed, 2015

\section{CONCLUSION AND RECOMMENDATION}

\section{Conclusions}

In the environment of fashion industry in Bandung, there are seven types of intelligence identified, namely: (a) intellectual quotient (IQ); (b) emotional intelligence (EQ); (c) spiritual intelligence (SQ); (d) social intelligence (SI); (e) physical intelligence (PQ); (f) adversary Quotient (AQ); and (g) culture-Art quotient which are able to contribute in the forming of the entrepreneurial spirit.

From those seven intelligences, it is known the ranking based on their importance in shaping the entrepreneurial spirit, namely (i) spiritual intelligence; (ii) Adversity Quotient; (iii) arts and cultural intelligence; (iv) social intelligence; (v) intellectual intelligence; (vi) emotional intelligence and (vii) physical intelligence. 


\section{Recommendations}

For academician, this study has the weakness by not differentiating business scale and is confined to the small and medium-scale enterprises. Therefore, the next studies intended in developing this research should: (a) expand the unit of analysis by increasing the number of unit of analysis and the scale of micro and large enterprises; (b) in the discussion, divide into groups of business scale, so the types and indicators of intelligences required in forming the entrepreneurial spirit will become more varied in accordance with the scale of the business. For the practitioners who are going to use the results of this study as a basis for making policies related to the HR management, specifically associated with arranging intelligence model, competency model built for the need of recruitment, selection, and development of its human resources, should consider the rank of importance of the various indicators forming the entrepreneurial spirit.

\section{REFERENCE}

Aristarini Luh, I Ketut Kirya, Ni Nyoman Yulianthini, (2014). Pengaruh Pengalaman Kerja, Kompetensi Sosial dan Motivasi Kerja Terhadap Kinerja Karyawan Pada Bagian Pemasaran PT. Adira Finance Singaraja. Journal of Bisma Universitas Pendidikan Ganesha Jurusan Manajemen, 2 (11), 1.

Baltes, P. B. (1997). On the incomplete Architecture of human ontogeny: Selection, Optimisation, and compensation as foundation of developmental theory. American Psychologist, 52(4), 366-380.

Beltran, G. J., \& Miguel, P. (2014). Doing Culture, doing business: A new entrepreneurial spirit in the Argentine creative industries. International Journal of Cultural Studies, 17(1), 39-54

Bergmann, H., Hundt, C., \& Sternberg, R. (2016). What Make Student Entrepreneurs? On the relevance (and irrelevance) of the university and the regional context for student startups. Small Business Economics, 47(1), 53-76. Chakraborty, S., Thompson, J. C., \& Yehoue, E. B.
(2016). The Culture of entrepreneurship. Journal of Economic Theory, 163, 288-317.

Demirel, E. T., Dusukcan, M., \& Olmez, M. (2012). The impact of areas of multiple intelligence on entrepreneurial behavior. African Journal of Business Management, 6(1), 415-421.

Galor, O., and Michalopoulos, S. (2009). The Evolution of Entrepreneurial Spirit and the Process of Development. IDEAS Working Paper Series from RePEc.

Goleman, D. (1995). Emotional Intelligence. New York: Bantam Books.

Grebel, T., Pyka, A., \& Hanusch, H. (2003). An evolutionary Approach to The Theory of Entrepreneurship. Industry and Innovation, 10(40), 493-514.

Levinson, D. J. (1978). The seasons of a man's life. New York: Ballantine Books.

Linley, P. A., Felus, A., Gillett, R., \& Joseph, S. (2011). Emotional Expression and Growth Following Adversity: Emotional Expression Mediates Subjective Distress and is moderated by Emotional Intelligence. Journal of Loss and Trauma, 16, 387-401.

McCrae, R. R, \& Costa, P. T. Jr. (1999). A Five-Factor Theory of personality. In I.A. Pervin, \& O.P. Jphn (Eds), Handbook of Personality: Theory and research (pp,139-153) (2nd ed.). New York: Guilford Press.

Robbins, S. P., \& Judge, T. A. (2013). Organizational Behavior (15th ed.). New Jersey: Prentice Hall.

Singiliene, V., \& Skeriene, S. (2015). Expression of Leaders' Spiritula Intelligence in a Context of Service Organisations: a Gender Approach. Procedia-Social and Behavioral Sciences, 213, 758-763.

Suyono, H. (2007). Social Intelligence. Yogyakarta : Ar Ruzz Media. 